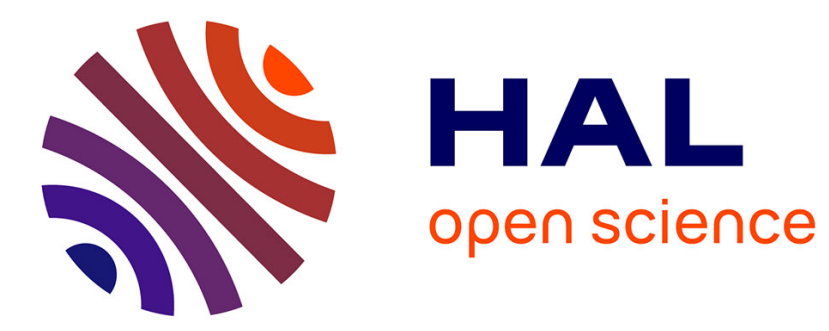

\title{
LONG-RANGE ICOSOHEDRAL SYMMETRY IN A METALLIC PHASE OBSERVED BY FIELD ION MICROSCOPY
}

\author{
A. Melmed, R. Klein
}

\section{> To cite this version:}

A. Melmed, R. Klein. LONG-RANGE ICOSOHEDRAL SYMMETRY IN A METALLIC PHASE OBSERVED BY FIELD ION MICROSCOPY. Journal de Physique Colloques, 1986, 4 (C2), pp.C2287-C2-290. 10.1051/jphyscol:1986243 . jpa-00225677

\section{HAL Id: jpa-00225677 https://hal.science/jpa-00225677}

Submitted on 1 Jan 1986

HAL is a multi-disciplinary open access archive for the deposit and dissemination of scientific research documents, whether they are published or not. The documents may come from teaching and research institutions in France or abroad, or from public or private research centers.
L'archive ouverte pluridisciplinaire HAL, est destinée au dépôt et à la diffusion de documents scientifiques de niveau recherche, publiés ou non, émanant des établissements d'enseignement et de recherche français ou étrangers, des laboratoires publics ou privés. 


\title{
LONG-RANGE ICOSOHEDRAL SYMMETRY IN A METALLIC PHASE OBSERVED BY FIELD ION MICROSCOPY
}

\author{
A.J. MELMED and R. KLEIN \\ National Bureau of Standards, Gaithersburg, MD 20899, U.S.A.
}

Resume

$L^{\prime}$ observation directe, par microscopie a champ ionique d'un alliage $d^{\prime}$ Aluminium et de Manganese (Mn:12\% Atomique) confirme la precedente mise en evidence, par des techniques de diffraction, d'une conformation icosonedrale a grande èchelle. De plus on remarque une grande quantite de desordre oristallin localise" presentant de nombreux defauts de structures "antiphase boundaries". L" existence d'un maclage systèmatique, qui aurait pu expliquer la symetrie d'orientation observeè, n'a pas pu etre demontreè.

\section{Abstract}

Direct observations by Field Ion Microscopy of an Al-12 at.\% alloy confirm the earlier determination, by diffraction techniques, of icosohedral long range orientational order. Additionally, a large amount of local disorder, replete with defects or antiphase boundaries, is found. There is no evidence for systematic twinning which might account for the observed orientational symmetry.

Recent observations of rapidly-cooled Al-12 at.\% Mn by transmission electron microscopy (TEM), electron diffraction in TEM, and x-ray diffraction indicated a structure characterized by long-range icosohedral symmetry and no translational symmetry (1). Considerable theoretical effort ensued and various models have been proposed to account for the diffraction data, including aperiodic, modulated and other structures (2). Multiple twinning in an otherwise normal crystal structure was proposed immediately to account for the observations and, although thoroughly discounted (1) in the first TEM investigation, was given support by a later TEM study (3). We began an FIM investigation of this material to confirm the validity of these conclusions in the real-space atomic structure, and to learn details of the atomic packing, which are not available from the diffraction data.

The alloy was prepared in the form of long ribbons and supplied to us in ribbon-fragments, a few $\mathrm{mm}$ in width, $1-2 \mathrm{~cm}$ in length and $3-4 \times 10^{-3} \mathrm{~mm}$ thick. Slivers, a few millimeters long, partially or completely broken from the edges of the (very brittle) larger fragments, were found in ample quantity for our purposes, and were easily clamped in a bent gold wire attached to the FIM specimen holder. FIM-sharp tips were made by electropolishing in about $25 \% \mathrm{HCl}$ in glycerin, using a few volts A.C. under an optical microscope (4), and finally rinsing in methanol. Imaging was done in hydrogen at $78 \mathrm{~K}$ or in hydrogen or neon at about $30 \mathrm{~K}$ in an unbaked FIM. Low-temperature neon imaging after initial field evaporation in hydrogen gave the best results. 
Thus far, we have studied about ten specimens of the as-cooled material and a few from material which had been annealed. FIM micrographs illustrative of these results are shown in figure 1. The dark bands are regions which field evaporated relatively rapidly, so that they did not experience a sufficient field strength when the voltage was adjusted for best imaging of the other region. They undoubtly correspond to the Ad-rich sheathing around and penetrating into the icosonedral phase, reported in the early TEM work (1). The relatively bright regions constitute the alloy phase of interest.

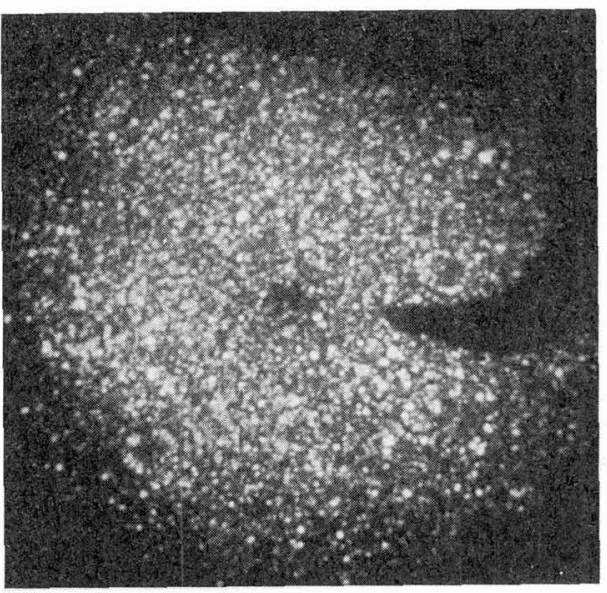

A

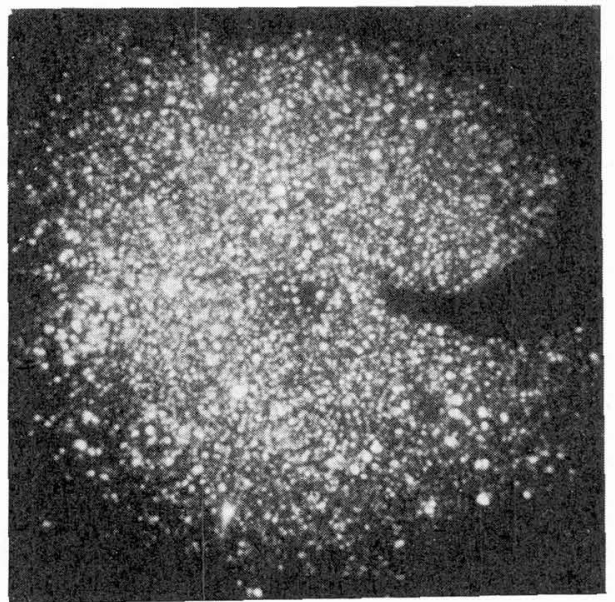

C

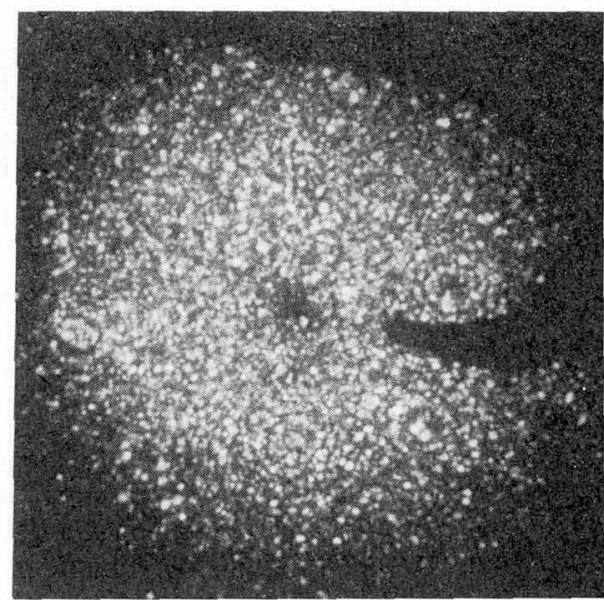

B

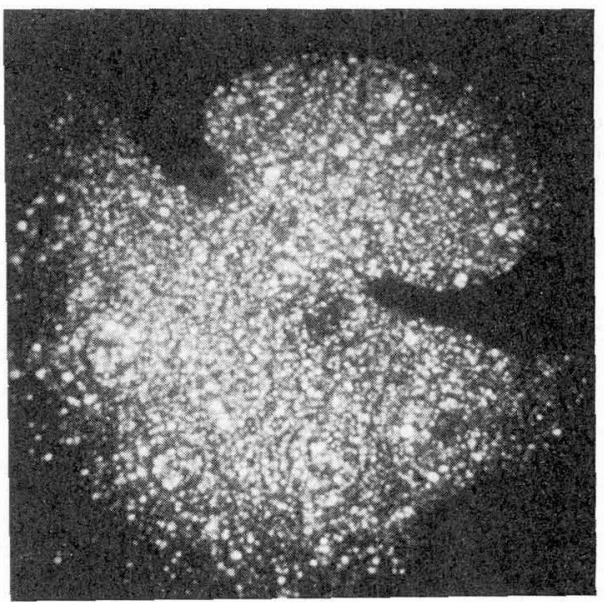

D

Figure 1. Sequence of neon field ion micrographs of Al-12 at.\% Mn (about $17 \mathrm{kV}$ and $30 \mathrm{k}$ ). Distance across image corresponds to about $100 \mathrm{~nm}$.

Continued field evaporation during FIM imaging produced the "collapsing rings" effect typical in field evaporation of a crystalline specimen. These ring structures are visible in the micrographs of figure 1, photographed during slow 
field evaporation (about 1 collapsing ring per 3-5 sec.), and imply certain structural aspects of the alloy phase. The overall symmetry of the specimen, over at least 1000A, is pentagonal, with 2-,3- and 5-fold rotational symmetry poles in locations which are consistent with the long-range icosohedral symmetry determined form the diffraction studies (1). This can be seen figure 2. No other symmetry is consistent with the micrographs. Additionally, the appearance of ring structures resulting from field evaporation implies some degree of organization of the atoms into planes (5).

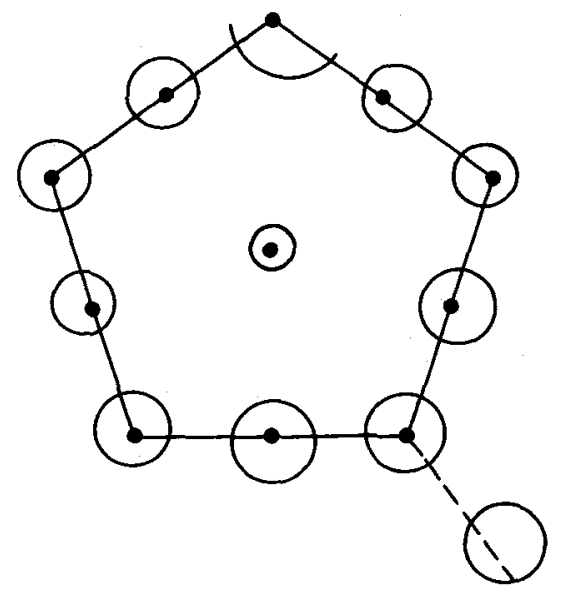

Figure 2. Superposition of a regular pentagon on a tracing of the major pole positions for a sequence of four field ion micrographs.

Occasionally, during the course of field evaporation, additional collapsing ring structures appeared and then disappeared upon further evaporation of perhaps 20-50 layers. Sometimes they were along zone lines and sometimes not. In general, the micrographs displayed a rather poor short-range order, in which thus far we have not found systematic structural features. Often small loops of atoms, about 3-5 atoms in diameter were also observed. Close inspection of the micrographs reveals a patchiness with sub-regions of about 5-10 nm extent, exhibiting some semblance of order within each patch. This patchiness appears to be correlated with some of the dark-field TEM observations (3).

As seen in $f$ igure 3 , a defect would sometlmes appear intersecting a major pole, or elsewhere. These may be examples of micro-twinning. In any case, they persisted for only a few layers in depth. No evidence was found for multiple twinning which could explain the observed long-range symmetry. It should also be noted that the apparent degree of order as developed by the field evaporation process and evidenced by the ring images was consistently less at the 5-fold poles than at the $2-$ and 3-fold poles. 


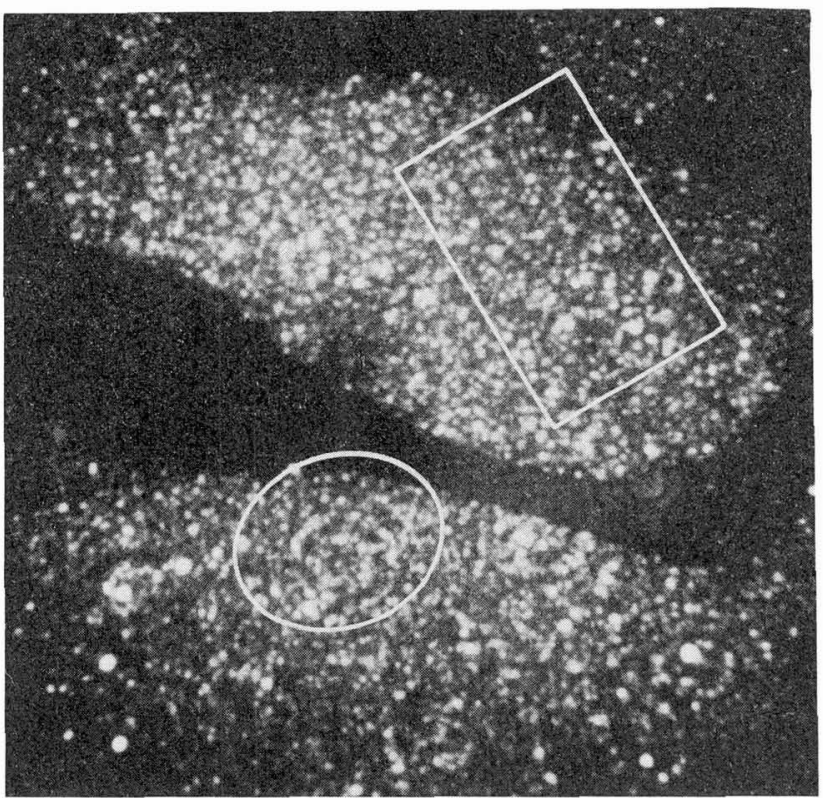

Figure 3. Neon field ion micrograph of Al-12 at.\% Mn (about $16 \mathrm{kV}$ and $30 \mathrm{k}$ ). Oval encloses defective 2-fold pole region, and rectangle encloses a prominent defect. Distance across image corresponds to about $100 \mathrm{~nm}$.

Thus, FIM has confirmed, in real-space, the major conclusions from the early diffraction studies (1) and has also revealed a considerably disturbed microstructure. Undoubtedly, some of the apparent disorder is artifactitious, due to the binary composition of the alloy, but the main features reported here are not subject to this uncertainty.

Acknowledgement: The authors appreciate the gift of specimen material from and discussion with Dr. J. W. Cahn.

References

1. D. Shechtman, I. Blech, D. Graties and J. W. Cahn, Phys. Rev. Lett. 53 (1984) 1951-1953.

2. D. R. Nelson and B. I. Halperin, submitted to Science.

3. R. D. Field and H. L. Fraser, Mat. Soi. Eng. 68 (1984-1985) L17-L21.

4. A. J. Melmed and J. J. Carroll, J. Vac. Sci. Technol. A2(3) (1984) $1388-1389$.

5. E. W. Miller and T. T. Tsong, "Field Ion Microscopy Principles and Applications," American Elsevier Publishing Co., Inc., New York (1969). 